\title{
The Effect of Perception and Motivation of Students to Interest in Choosing Tax Concentration
}

\author{
Zulia Hanum ${ }^{1}, J_{a s m a n}$ Saripuddin Hasibuan ${ }^{2}$ Iskandar Muda $^{3}$ \\ $\left\{\right.$ zuliahanum@umsu.ac.id ${ }^{1}$ \} \\ ${ }^{1,2}$ Univercity of Muhammadiyah Sumatera Utara, Jalan Kapten Mucthar Basri no.3 Medan, Indonesia \\ ${ }^{3}$ University of North Sumatera, Indonesia
}

\begin{abstract}
This study aims to examine the effect of perceptions and motivations of accounting students on tax concentration at the Faculty of Economics and Business, Muhammadiyah University of North Sumatra on the interest in choosing a tax concentration. Measurement of the influence of perceptions and motivations of accounting students on the interest in choosing a tax concentration is a questionnaire instrument. The sample which was used in this study was 130 students who were taking tax concentration and data that can be processed were 113 respondents using SPSS 22. The data analysis technique used was multiple linear regression by looking at the goodness of fit namely the coefficient of determination, the statistical value $F$ and statistics t. The results of this study indicated that there were influences both partially and simultaneously the perceptions and motivations of students in the interest of choosing taxation concentration. This showed that there was a student interest in the concentration of taxation.
\end{abstract}

Keywords: student perception, student motivation and interest in choosing taxation,concentration

\section{Introduction}

Increased economic development in Indonesia is followed by improvements in various sectors. One of them is the education sector, the demand for quality and competent workforce to support the improvement of economic development, using educational institutions to produce qualified graduates, in order to be able to compete in the world of work. Currently it is in need of an educational institution that can produce good educated energy, by striving to maintain the quality and competence of graduation so that they have adequate technical and moral competencies to get job opportunities. In addition, educational institutions must also prepare prospective graduates so that later they can choose a career that suits their abilities. Accounting study program, either in state universities or private universities, Under a worldwide tax system, taxes are levied on the worldwide (Douglas A. Shackelford, JanaS.Raedy, 2012) Research in accounting for income taxes. income of resident corporations (Dharmapala, 2018)

There are various factors that encourage students to choose accounting study programs, such as the existence of employment opportunities after graduating from college, the encouragement of family and the influence of friends in their neighborhood.Accounting is one of the departments that are mostly interested in students today (Mattia Anesa, Nicole Gillespie, A. Paul Spee, 2018) Previous research results state that the average student chooses accounting majors which is driven by their desire to become professionals in the accounting field Moreover, studentsare also motivated by the assumption that accountants are much needed by many organizations and companies that will come especially in Indonesia. 
However, at this time, there are certain persons that raise doubtsthe reliability of the Higher Education Accountants produces professional accountants in Indonesia.

In the world of work, there are several careers that can be run by accounting scholars, such as public accountants, government accountants, accounting accountants, or internal accountants. The existence of several careers for accounting graduates shows that accounting scholars can choose a particular career in the world of work, accounting students as prospective accounting graduates, can consider what career they will choose later.

Motivation is basically a process to try to influence someone to do something they want. In other words, it is an external motivation for someone to want to do something. Learning motivation of a student will increase with the clarity of the relationship between working hard and obtaining financial and non-financial awards in the form of developing talent, manythings that studentsthose who get the satisfaction of learning facilities will get a good job. which provide a complete picture of the economic situation of the company. The quality of accounting (financial) statements of the company depends on the quality of financial indicators and their predictive ability (Eva Sikorováa, Lucie Meixnerováb, Michal Menšíkc, 2015) The success of a college in achieving its goals is not only because of its facilities but also its students. Student learning motivation can also be defined as a condition in students that encourages and directs their behavior to the goals they wantin his achievement in attending higher education. Ideally, the aim of students in attending higher education is to master the field of study they are studying. So that in learning each learning material, students are encouraged to master the learning material well.

A clear student interest and career plan will be very useful in program preparation so that lecture material can be delivered effectively for students who need it. Career planning is very important to achieve success (Berry, 1997; Messmer, 1997; and Peolillo et al, 1998) in Rasmini (2007). Therefore, a stimulation is needed to make students begin to think seriously about their desired career since they were in college so that students can utilize campus time and facilities optimally. The role of educator accountants as stimulators for this matter is considered very important (Rasmini, 2007).

The Faculty of Economics and Business is the Faculty in UMSU which, and one of the departments in the faculty of economics and business is the accounting department, there is a concentration at the faculty of Economics and Business UMSU concentration. The concentration consists of (five) concentrations, namely: audit concentration, tax concentration, management accounting concentration, and financial accounting concentration.

The need for taxation experts is huge, especially since the Directorate General of Taxation of the Republic of Indonesia tightened the application of Indonesian tax regulations, and many cases involving various companies. The company is currently improving and looking for workers who, in addition to understanding accounting, can also understand tax calculations. Sometimes a company seeks labor for the needs of each department, namely its own accountants and tax workers themselves. With the existence of a taxation concentration accounting department, students get two knowledges at once, namely accounting and taxation sciences which are equivalent to Brevet A and B. Both of these sciences are closely related because tax calculation will not be separated from accounting calculations and vice versa. Companies will be more likely to choose graduates who have both of these knowledge than to recruit two workers with two different departments because it will save costs and will work faster. Companies that require tax accounting personnel are usually private companies (public companies, audit companies), departments or government agencies,tax offices, nongovernment organizations, and others. 
Therefore, in addition to getting debriefing material obtain in college namely accounting and taxation material, someone who willbe choosing a career also requires an external preparation such as soft skills debriefing, namely how they can work together in teams, building effective communication with others so that they are able to be competent in the world of work. Career is one of the goals of the individual to achieve a higher level.With this research, the hope of this study can understand well the supporting factors that influence the work field of accounting students of Muhammadiyah University of North Sumatra after becoming accounting graduates. With this also the research is expected to be a reference to further research.

Based on the background above, the researcher chosees this research to find out whether students' perceptions and motivations affect the interest in choosing taxation concentration.

\section{LITERATURE REVIEW}

According toIndonesia dictionary (Alwi: 2003) perception is the response or direct acceptance of an or is a process someone knows several things from panca (sensory sense: 1995) that perception is a process in which someone organizes and observes sensory impressions in usage give a certain meaning to the environment.

\section{a. Perception}

Many understanding perceptions are presented by various experts, each expert interpreted according to his scientific discipline. The conception of perception itself should have long been developed in various psychological theoriesand a specific theory regarding perceptions that are quite influential is attribution theory. Attribution theory according to Saparinah (1976) is a theory about how people make causal explanations or about how they answer questions that begin with why? the theory emphasizes the information that people use in drawing causal conclusions.

According to Atkison (sobur alex, 2003) perception has two main functions of the Perpsi system, namely:

a. Determine the location of an object (Localization)

Determining the loasiof an object, must first segregate the object and then organize the object into a group. This process was first examined by Gestalt, which put forward organizational principles. One of these principles is that a person organizes a stimulus to an area that matches the image and setting. Another principle states the basic basis is used to classify objects, including closeness closeness, continuity and similarity.

b. Specifying Object Type (introduction)

The introduction of an object requires its classification in the category and its basement, especially in the form of an object. In the early stages of the introduction of the visual system uses retinal information to describe objects in terms of characteristics, such as lines and angles. Cells that detect these features (feature detectors) have been found in the viscous cortex. Next, match the description of the form stored in memory to determine the most suitable one.

\subsection{Motivation}


According to Terry G (1986) motivation is a belief that is found in a person who encourages him to do an action (behavior). According to Widyastuti, et al in Muhammad Iqbal (2011) motivation is often interpreted as an encouragement. The encouragement or energy is the movement of the soul and body to do, so motivation is an energy that drives menaa to behave in their actions that have a purpose.

Supardi and (Anwar, 2004) states that motivation is a state of affairs in a person that encourages individual desire to carry out certain activities in order to achieve goals. Motivation that exists in someone who will realize a behavior that is directed at the goal of achieving satisfaction goals.

(Siagian P, 2002)_states that what a person wants from his work in general is something that has significance for himself and for the agency. Motivation is the background of an individual to act to achieve a certain goal. Someone who deliberately binds themselves to be part of the organization has a different background, the other one is so that they can interact with humansothers and so that their life needs can be met. Motivation is important because with this motivation it is expected that each individual will work hard and enthusiastically to achieve high work productivity.

Motivation is divided into 2, namely: external and internal motivation. External motivation comes from outside a person, such as speakers in seminars, friends, family, magazines, books and so on. While internal motivation is a form of motivation that comes from within from one person.

\subsection{Interest}

Interest is a factor of psychology that is formed and developed by the existence of innate influences and environmental influences. But environmental factors are the most dominant factor that can affect interest. At first the interest is centered on the individual, then centering on other people and other objects in their environment.

According to Muhammadinah (2009), interest is defined as desire, desire or liking. Interest is personal and closely related to attitude. Interest and attitude are aware of prejudice, and interest is also important in making decisions. Interest can cause someone to be more active towards something that has attracted his interest. Interest is an individual aspect, which is related to mental loneliness, also in the view that interest is an individual nature that has a role that is closely related to the whole. Interest is defined as a condition that occurs when a person sees temporary traits or meanings of a situation that are related to his own desires or needs. Therefore, what a person sees will certainly arouse his interest, a number of which are seen as having a relationship with his own interests. Bernanrd in Sardiman (2008) say that lower interest does not arise suddenly or spontaneously, but rather arises from participation, experience, habits when studying or working.

\subsection{Conceptual Framework}

In career selection, interest is a mental device consisting of a combination, combination and mix of feelings, hopes, prejudices, fear, fear and tendencies that can lead individuals to a particular choice. It is impossible for someone who is not interested in something to work will be able to finish the job well. I Gusti (2013) at Udayana University found that simultaneously accounting majors had perceptions, motivations that did not have a significant effect on career interests in taxation. However, this research is in line with research is conducted by Yulia S. (2010) that students' perceptions and motivations significantly influence career selection in the field of taxation. 
Career selection is a process or activity of individuals in an effort to prepare themselves to enter a career related to work through a series of targeted and systematic activities processes (Dwi and Setiawan, 2012). Career selection for students majoring in accounting is the initial stage of career formation after completing college. There are several obstacles that students will face in determining careers such as career uncertainty, economic and technological challenges and social and cultural challenges.

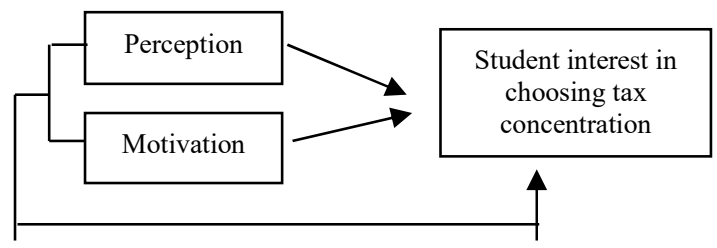

Fig.1. Conceptual Framework

\section{Research Methods}

The data used in this study is to use primary data in the form of questionnaires. Questionnaire is a data collection technique that is done by giving a set of questions or written statements to respondents to be answered (Sugiyono, 2015).

Methods Data analysis used in this studv was Multiple Linear Regression. Multiple linear analysis is an analysis of the relationsh (1) reen the dependent variable and two or more independent variables (Arikunto. 2006 p. 290). In accordance with the formulation of the objectives and hypotheses of this study, the multiple linear regression method relates one dependent variable to the Independent variable in a single predictive model. After getting a good research model, testing using Multiple Linear Regression with the help of SPSS Software is:

Where;

$$
Y=\beta 0+\beta 1 X 1+\beta 2 X 2+\varepsilon
$$

$\mathrm{X} 1 \quad$ : Perception

X2 : Motivation

Y : taxation concentration

$\beta 1 \& \beta 2$ : Coefficient

$\varepsilon \quad:$ Error Term

B0 : Constants

Testing the hypothesis in this study was used by multiple linear regression. Regression analysis was useful especially for the purpose of estimation, namely how independent variables were used to estimate the value of the dependent variable. The Dependent Variable is Taxation Concentration (Y), Independent variables are Perception (X1) and Motivation (X2). Data analysis techniques was used by SPSS 17.0 for Windows software tools.

\section{Research Results And Discussion}

Distribution of questionnaires were conducted by researchers from March 10 to 2018 there were 79 processed questionnaires from 91 questionnaires provided to all students who took the Audit concentration in the accounting department of Muhammadiyah University of North 
Sumatra, resulting in a respone rate of $87 \%$. The results of the questionnaire and its distribution can be seen from the following table.

Table 1. Questionnaire Distribution and Returns

\begin{tabular}{lcc}
\hline \multicolumn{1}{c}{ Information } & Total & Percentage \\
\hline $\begin{array}{l}\text { Numbered of questionnaires } \\
\text { distributed }\end{array}$ & $\begin{array}{c}91 \\
\text { people }\end{array}$ & $100 \%$ \\
\hline $\begin{array}{l}\text { Numbered of questionnaires } \\
\text { received }\end{array}$ & $\begin{array}{c}81 \\
\text { people }\end{array}$ & $89 \%$ \\
\hline The questionnaire is incomplete & 2 people & $2 \%$ \\
\hline Questionnaire that is filled & $\begin{array}{c}10 \\
\text { people }\end{array}$ & $11 \%$ \\
\hline Questionable questionnaire & $\begin{array}{c}79 \\
\text { people }\end{array}$ & $87 \%$ \\
\hline
\end{tabular}

Source : results processed by researchers

Table 2. Likert Measurement Scale

\begin{tabular}{lc}
\hline \multicolumn{1}{c}{ Question } & Weight \\
\hline Strongly agree (SA) & 5 \\
\hline Agree (A) & 4 \\
\hline Neutral (N) & 3 \\
\hline Disagree (D) & 2 \\
\hline Strongly disagree (SD) & 1 \\
\hline \multicolumn{2}{c}{ Source : Sugiyono (2016) }
\end{tabular}

Table 3. Profile of Respondents by Gender

\begin{tabular}{lllc}
\hline No. & Gender & Frequency & Percentage \\
\hline 1 & Man & 31 people & $39 \%$ \\
\hline 2 & Woman & 48 people & $61 \%$ \\
\hline Total & 79 people & $100 \%$ \\
\hline \multicolumn{2}{l}{ Source : The results are precessed by researchers }
\end{tabular}

Table 4 . Profile of Respondents by Force

\begin{tabular}{lllc}
\hline No. & Force & Frequncy & Percentage \\
\hline 1 & 2014 & 45 people & $57 \%$ \\
\hline 2 & 2015 & 34 people & $43 \%$ \\
\hline Total & & 79 people & $100 \%$ \\
\hline
\end{tabular}

Source : The results are precessed by researchers

Table 5. Profile of Respondents by Class

\begin{tabular}{llcc}
\hline No. & \multicolumn{1}{c}{ Class } & Frequncy & Percentage \\
\hline 1 & $\begin{array}{l}\text { Daytime taxation } \\
\text { concentration }\end{array}$ & 51 people & $65 \%$ \\
\hline 2 & Night taxation concentration & 28 people & $35 \%$ \\
\hline Total & & 79 people & $100 \%$ \\
\hline
\end{tabular}


From the table above, it can be concluded that the number of classes that most filled out the questionnaire was the afternoon class, which was 51 people or $65 \%$, while the night audit concentration class was 28 people or $35 \%$ of the total.

This variable data aimed to provide an overview of the research variables. The variables of this study consisted of perception, and interest as independent variables, while the career selection as Auditor in the Public Accountant Office was the dependent variable.

1. Dependent Variable Selection of Career as Auditor at KAP.

In the dependent variable, the career selection as auditor in KAP was done with five question indicators to 79 questionnaires, while the question indicators were in the following table.

Table 6. Answers to the Variable Selection Questionnaire of Career As an auditor at KAP

\begin{tabular}{|c|c|c|c|c|c|c|c|c|c|c|}
\hline \multirow[t]{3}{*}{ Statement } & \multicolumn{10}{|c|}{ Answer Option } \\
\hline & \multicolumn{2}{|c|}{ SA } & \multicolumn{2}{|r|}{ A } & \multicolumn{2}{|c|}{$\mathrm{N}$} & \multicolumn{2}{|c|}{$\mathrm{D}$} & \multicolumn{2}{|c|}{$\mathrm{SD}$} \\
\hline & $\mathrm{F}$ & $\%$ & $\mathrm{~F}$ & $\%$ & $\mathrm{~F}$ & $\%$ & $\mathrm{~F}$ & $\%$ & $\mathrm{~F}$ & $\%$ \\
\hline $\begin{array}{l}\text { I am convinced that a career as a } \\
\text { tax consultant in the tax } \\
\text { consultant's office is a promising } \\
\text { job }\end{array}$ & 6 & $7,6 \%$ & 56 & $70,9 \%$ & $\begin{array}{l}1 \\
7\end{array}$ & $21,5 \%$ & - & - & - & - \\
\hline $\begin{array}{l}\text { I am interested in becoming a tax } \\
\text { consultant because I like the field }\end{array}$ & 14 & $17,7 \%$ & 50 & $63,3 \%$ & $\begin{array}{l}1 \\
5\end{array}$ & $19 \%$ & - & - & - & - \\
\hline $\begin{array}{l}\text { The work of a tax consultant will } \\
\text { give satisfaction in working }\end{array}$ & 10 & $12,6 \%$ & 56 & $70,9 \%$ & $\begin{array}{l}1 \\
3\end{array}$ & $16,5 \%$ & - & - & - & - \\
\hline $\begin{array}{l}\text { I am interested in becoming a tax } \\
\text { consultant because I will get good } \\
\text { facilities }\end{array}$ & 11 & $13,9 \%$ & 50 & $63,3 \%$ & $\begin{array}{l}1 \\
8\end{array}$ & $22,8 \%$ & - & - & - & - \\
\hline $\begin{array}{l}\text { I will be an auditor at tax } \\
\text { consultant in the tax consultant's } \\
\text { office }\end{array}$ & 22 & $27,8 \%$ & 44 & $55,7 \%$ & $\begin{array}{l}1 \\
3\end{array}$ & $16,5 \%$ & - & - & - & - \\
\hline
\end{tabular}

Table 7 . Answer Perception Variable Questionnaire (X1)

\begin{tabular}{|c|c|c|c|c|c|c|c|c|c|c|}
\hline \multirow[t]{3}{*}{ Statement } & \multicolumn{10}{|c|}{ Answer Option } \\
\hline & \multicolumn{2}{|c|}{ SA } & \multicolumn{2}{|r|}{ A } & \multicolumn{2}{|c|}{$\mathrm{N}$} & \multicolumn{2}{|c|}{$\mathrm{D}$} & \multicolumn{2}{|c|}{ SD } \\
\hline & $\mathrm{F}$ & $\%$ & $\mathrm{~F}$ & $\%$ & $\mathrm{~F}$ & $\%$ & $\mathrm{~F}$ & $\%$ & $\mathrm{~F}$ & $\%$ \\
\hline $\begin{array}{l}\text { Thinking of being a tax consultant } \\
\text { will provide a great opportunity for } \\
\text { tax concentration accounting } \\
\text { students }\end{array}$ & 25 & $31,6 \%$ & 47 & $92,5 \%$ & 7 & $8,9 \%$ & - & - & - & - \\
\hline $\begin{array}{l}\text { I am interested in a career as a tax } \\
\text { consultant because I am happy with } \\
\text { the tax accounting course }\end{array}$ & 28 & $35,4 \%$ & 42 & $53,2 \%$ & 9 & $11,4 \%$ & - & - & - & - \\
\hline $\begin{array}{l}\text { I feel that before a career being an } \\
\text { auditor, a public accountant needs to } \\
\text { take part in training for career } \\
\text { development }\end{array}$ & 19 & $24,1 \%$ & 51 & $64,5 \%$ & 9 & $11,4 \%$ & - & - & - & - \\
\hline $\begin{array}{l}\text { I am interested in a career as a tax } \\
\text { consultant because it will add insight }\end{array}$ & 13 & $16,5 \%$ & 43 & $54,4 \%$ & 23 & $29,1 \%$ & - & - & - & - \\
\hline I am interested in becoming a tax & 20 & $25,3 \%$ & 43 & $54,4 \%$ & 16 & $20,3 \%$ & - & - & - & - \\
\hline
\end{tabular}


consultant because I am taking

taxation courses

Table 8 . Answers to Variable Interest Questionnaire (X2)

\begin{tabular}{|c|c|c|c|c|c|c|c|c|c|c|}
\hline \multirow[t]{3}{*}{ Statement } & \multicolumn{10}{|c|}{ Answer Option } \\
\hline & \multicolumn{2}{|c|}{ SA } & \multicolumn{2}{|r|}{ A } & \multicolumn{2}{|c|}{$\mathrm{N}$} & \multicolumn{2}{|c|}{$\mathrm{D}$} & \multicolumn{2}{|c|}{$\mathrm{SD}$} \\
\hline & $\mathrm{F}$ & $\%$ & $\mathrm{~F}$ & $\%$ & $\mathrm{~F}$ & $\%$ & $\mathrm{~F}$ & $\%$ & $\mathrm{~F}$ & $\%$ \\
\hline $\begin{array}{l}\text { I think that the learning process of } \\
\text { taxation courses will help when a } \\
\text { career becomes a tax consultant }\end{array}$ & 18 & $22,8 \%$ & 56 & $70,9 \%$ & 5 & $6,3 \%$ & - & - & - & - \\
\hline $\begin{array}{l}\text { I think that knowledge related will } \\
\text { be very beneficial in a career as a } \\
\text { tax consultant }\end{array}$ & 24 & $30,4 \%$ & 50 & $63,3 \%$ & 9 & $11,4 \%$ & - & - & - & - \\
\hline $\begin{array}{l}\text { I feel that before a career being a } \\
\text { tax consultant needs to take part in } \\
\text { training for career development }\end{array}$ & 19 & $24,1 \%$ & 51 & $64,5 \%$ & 9 & $11,4 \%$ & - & - & - & - \\
\hline $\begin{array}{l}\text { I think that a career will be a tax } \\
\text { consultant will be able to improve } \\
\text { analytical skills, decision making, } \\
\text { problem solving to solve tax } \\
\text { problems }\end{array}$ & 23 & $29,1 \%$ & 46 & $58,2 \%$ & 10 & $12,7 \%$ & - & - & - & - \\
\hline $\begin{array}{l}\text { I feel that a career as a tax } \\
\text { consultant will add interpersonal } \\
\text { skills such as the ability to work } \\
\text { together in groups }\end{array}$ & 16 & $20,3 \%$ & 55 & $62,6 \%$ & 8 & $10,1 \%$ & - & - & - & - \\
\hline
\end{tabular}

Table 9 . Multiple Linear Regression Equations

\begin{tabular}{|c|c|c|c|c|c|}
\hline \multicolumn{6}{|c|}{ Coefficients $^{2}$} \\
\hline \multirow[t]{2}{*}{ Model } & \multicolumn{2}{|c|}{ Unstandardized Coefficients } & \multirow{2}{*}{$\begin{array}{l}\text { Standardized Coefficients } \\
\text { Beta }\end{array}$} & \multirow[t]{2}{*}{$\mathrm{t}$} & \multirow[t]{2}{*}{ Sig. } \\
\hline & $\mathrm{B}$ & Std. Error & & & \\
\hline$\{$ Constant & 2,400 & 2,785 & &, 862 & ,391 \\
\hline Persepsi (X1) & ,488 &, 100 & ,458 & 4,894 &, 000 \\
\hline Minat (X2) & ,347 & ,347 & ,365 & 3,904 &, 000 \\
\hline
\end{tabular}

Then the multiple linear regression equation model is as follows:

$Y=2,400+0,488 \times 1+0,347 \times 2$

a. The constant coefficient is 2,400 which means that if both perception variables (X1) and interests (X2) are constant at 0 (zero) then the public accounting profession(Y) is 2,400.

b. Perception regression coefficient value $(\mathrm{X} 1)=0.488$, statistically shows that there is a positive influence on perception variables on the public accounting profession. Coefficient value of 0.488 means that if the perception rises by 1 unit, then the value of the public accounting profession increases by 0.488 assuming a constant interest variable.

c. Interest regression coefficient value $(\mathrm{X} 2)=0.347$, statistically shows that there is a positive influence of interest variables on the public accounting profession. Coefficient 
value of 0.347 means that if interest rises by 1 unit, then the value of audit quality increases by 0.347 assuming a constant perception variable.

d. Adjusted R square value of 0.318 means that $31.8 \%$ of the public accounting profession is influenced by perception variables (X1) and interests (X2), while $68.2 \%$ is influenced by other factors.

Table 10. Autocorrelation Test Results

\begin{tabular}{|l|l|l|l|l|l|}
\hline \multicolumn{5}{|c|}{ Model Summary $^{\mathrm{u}}$} \\
\hline Model & $\mathrm{R}$ & $\begin{array}{l}\mathrm{R} \\
\text { Squere }\end{array}$ & $\begin{array}{l}\text { Adjusted R } \\
\text { Squere }\end{array}$ & $\begin{array}{l}\text { Std. Error of the } \\
\text { Estimate }\end{array}$ & $\begin{array}{l}\text { Durbin- } \\
\text { Watson }\end{array}$ \\
\hline 1 &, $579^{2}$ &, 318 &, 318 & 1,7366 & 1,931 \\
\hline \multicolumn{6}{|c|}{ a. Predictors: (Constant), Minat (x2), Persepsi (X1) } \\
\hline b. Dependent Variable: Pemilihan Sebagai auditor di Kantor Akuntan Publik (Y) \\
\hline
\end{tabular}

Sumber: Data diolah oleh SPSS 22

Table 11. Simultaneous Test Results

\begin{tabular}{|c|c|c|c|c|c|c|}
\hline \multicolumn{7}{|c|}{ ANOVA $^{\mathrm{a}}$} \\
\hline \multicolumn{2}{|c|}{ Model } & Sum of Squeres & df & Mean squere & $\mathrm{F}$ & Sig. \\
\hline \multirow[t]{3}{*}{1} & Reggression & 115.829 & 2 & 57,914 & 19,203 &, $000^{2}$ \\
\hline & Residual & 229.209 & 76 & 3,016 & & \\
\hline & Total & 345.038 & 78 & & & \\
\hline \multicolumn{7}{|c|}{ a. $\quad$ Devendent Variable: Pemilihan karir sebagai auditor di kantor akuntan publik (Y) } \\
\hline \multicolumn{7}{|c|}{ b. Predictors: (Constant), Minat (x2), Persepsi (X1) } \\
\hline
\end{tabular}

Sumber: Data diolah oleh SPSS 22

Table 12 . Partial Test Results

\begin{tabular}{|c|c|c|c|c|c|}
\hline \multicolumn{6}{|c|}{ Coefficients $^{2}$} \\
\hline \multirow[t]{2}{*}{ Model } & \multicolumn{2}{|c|}{ Unstandardized Coefficients } & Standardized Coefficients & \multirow[t]{2}{*}{$\mathrm{t}$} & \multirow[t]{2}{*}{ Sig. } \\
\hline & $\mathrm{B}$ & Std. Error & Beta & & \\
\hline$\{$ Constant $\}$ & 2,400 & 2,785 & &, 862 & ,391 \\
\hline Persepsi (X1) & 488 &, 100 & ,458 & 4,894 &, 000 \\
\hline Minat (X2) & ,347 & ,089 & ,365 & 3,904 &, 000 \\
\hline
\end{tabular}

a. Dependent Variable: Pemilihan karir Sebagai auditor di Kantor Akuntan Publik (Y)

Sumber: Data diolah oleh SPSS 22

To test the hypothesis one is known that the hypothesis is accepted, this can be seen from multiple linear regression analysis with partial test shows that the interest of accounting students shows a probability value (Sig) of 0,000 and a $t$ value of 4.894 . Because the probability value ( $\mathrm{Sig})$ is smaller than $\alpha(0.05)$ this means that the perception of accounting students has a significant effect on the choice of career as an auditor in the Public Accounting Firm.

To test the second hypothesis it is known that the hypothesis is accepted, this can be seen from the multiple linear regression analysis with a partial test shows that the interest of accounting students shows a probability value (Sig) of 0,000 and a t value of 3.904 . Because the probability value (Sig) is smaller than $\alpha(0.05)$ this means that the interest of accounting students has a significant effect on career selection as an Auditor in the Public Accountant Office. 
The positive interest is shown by the accounting major students in this study states that, most accounting students believe that the public accounting profession is a profession that is seen as promising bright prospects because this profession provides intellectual challenges and invaluable learning experiences.

The third hypothesis (H3) states that simultaneously accounting majors have positive perceptions and interests in choosing a career as an auditor in a public accounting firm. The results of this study are also supported by the results of Yulia S. (2010) research with the title Influence of the perceptions and interests of students majoring in accounting regarding the public accounting profession of his career choices as a public accountant in accounting students at Semarang State University who find that perceptions and interests significantly influence both simultaneously or partially towards career choices as a public accountant.

\section{Conclusion}

Based on the results of research was conducted by the author regarding the Influence of Perception and Interest in the Choosing of a career as an Auditor in a Public Accountant Office in accounting student Muhammadiyah Universityof North Sumatra, conclusions can be drawn according to the hypothesis that has been formulated that:

a. Students majoring in accounting have a positive perception and interest in choosing a career as an Auditor in a Public Accountant Office simultaneously. This shows that the two variables have a significant influence on the perspective of accounting students on the profession of auditors in public accounting firms. In addition, perceptions and interests influence the assessment of accounting students on the selection of careers as auditors in public accounting firms that have not yet been optomal. With good perceptions and interests, this will be a good signal for the development of the accounting profession in the future.

b. Students majoring in accounting have a positive perception of the Auditor profession in the Public Accounting Firm. This shows that most of the students majoring in accounting, especially the concentration of the Audit Faculty of Economics, Muhammadiyah University of North Sumatra, view the profession as an Auditor in the Public Accountant Office as a respected and attractive profession so that later this profession can become a profession of interest by accounting students.

c. Accounting students have a positive interest in the profession of being an Auditor in a Public Accountant Office. This shows that most of the students majoring in faculty accounting, especially concentration of audit, have positive interests to become auditors in the public accounting firm in the future. With this positive interest, it is expected that in the future this profession will become a superior profession and become a priority in a career.

\section{References}

[1] Anwar (2004) Pendidikan Ecakapan Hidup (Life Skill Education) KOnsep Dan Aplikasi. Alfabeta. Bandung.

[2] Dharmapala, D. (2018) 'No Tax sparing agreements, territorial tax reforms, and foreign direct investmenTitle', Journal of Public Economics, 169, pp. 89-108.

[3] Douglas A. Shackelford, JanaS.Raedy, J. R. G. (2012) 'Research in accounting for income taxes', Journal of Accounting and Economics, 53, pp. 412-434.

[4] Eva Sikorováa, Lucie Meixnerováb, Michal Menšíkc, V. P. (2015) 'Descriptive Analysis and Spatial Projection of Performance among the Small and Middle 
Enterprises in the Olomouc Region in the Czech Republic in the Context of Accounting and Tax Legislation', in Procedia Economics and Finance, pp. 528-534.

[5] Mattia Anesa, Nicole Gillespie, A. Paul Spee, K. S. (2018) 'The legitimation of corporate tax minimization. Accounting Organizations and Society'.

[6] Siagian P, S. (2002) 'Kiat Meningkatkan Produktivitas Kerja', in. Rineka,Jakarta.

[7] sobur alex (2003) Psikologi Umum. Bandung: Setia Pustaka. 